\author{
Anna CICHECKA \\ University of Wroclaw \\ anacichecka@gmail.com
}

\title{
EAC - AN ANSWER FOR REGIONAL PROBLEMS OR FAILED SOLUTIONS IN EAST AFRICA?
}

ABSTRACT One of the definitions states that regionalism means a common policy or project aimed at increasing informal links and economic, political and social transactions which strengthen integration processes, intensify intergovernmental cooperation and create regional identity among the community. According to the above, it was assumed that firstly, states in a group are stronger and more effective and secondly, that regionalism and regionalization may be regarded as a way to solve some regional problems and to contribute to the development of individual states. This narrative became especially attractive for underdeveloped and dysfunctional regions as it offered an opportunity for changes. As a result, a quantitative increase in regional initiatives started. The article is dedicated to the integration processes in the East Africa region. The main aim of the paper is to examine the situation in East Africa, regarding the role that the East African Community has played in this area. Moreover, an attempt has been made to analyze the integration model adopted by the organization and find out if the EAC is able to solve the main regional problems or rather to propose a failed solution and maintain dysfunctional patterns in the organization.

Key words: EAC, East Africa, integration, regionalism 


\section{INTRODUCTION}

Regional initiatives in sub-Saharan Africa gained importance at the turn of $21^{\text {st }}$ century. On the one hand, they contributed to the increase in regional projects, and on the other, they strengthened the processes of regionalization. At the same time, it has been observed that the popular meta-narrative of African unity, which referred to the idea of Pan-Africanism, started to be accompanied by various integration concepts at the level of individual regions. ${ }^{1}$ One of the definitions stated that regionalism means a common policy or project aimed at increasing informal links and economic, political and social transactions which strengthen integration processes, intensify intergovernmental cooperation and create regional identity among the community. ${ }^{2}$ According to the above, it was assumed that firstly, states in a group are stronger and more effective and secondly, that regionalism and regionalization may be regarded as a way to solve some regional problems and to contribute to the development of individual states. This narrative became especially attractive for underdeveloped and dysfunctional regions as it offered an opportunity for changes. As a result, a quantitative increase in regional initiatives started.

This article is dedicated to the integration processes in the East Africa region. The main aim of the paper is to examine the situation in East Africa, regarding the role that the East African Community (EAC) has played in this area. Moreover, an attempt has been made to analyze the integration model adopted by the organization and discover if the EAC is able to solve the main regional problems or rather to propose a failed solution as an answer to them.

The paper first gives an overview of the historical background and investigates the ideas that influenced the integration model adopted by the EAC. In the second section the specific nature of the cooperation in the East Africa region is characterized while the third part traces the achievements and failures of the EAC. The last part of the paper is devoted to a conclusion.

\section{HYPOTHESIS AND METHODOLOGY}

The hypothesis is that the integration model adopted by the EAC maintains dysfunctional patterns in the organization and among partner states.

Moreover, in observing various levels of interdependence on this issue one is led to several research questions, such as:

R. Gibb, "Regional Integration and Africa's Development Trajectory: Meta-Theories, Expectations and Reality", Third World Quarterly, vol. 30, no. 4 (2009), p. 701, at <https://doi.org/10.1080/ 01436590902867136>.

2 E. Stadtmüller, "Regionalizm i regionalizacja jako przedmiot badań naukowych w stosunkach międzynarodowych”, in K. Jędrzejczyk-Kuliniak et al. (eds.), Regionalizacja w stosunkach międzynarodowych. Aspekty polityczno-gospodarcze, Toruń 2008, pp. 22-26. 
1. What role does the EAC play in the East Africa region?

2. What are the characteristic points in East African regional cooperation?

3. What kind of achievements and failures does the EAC have?

4. What narratives accompany the EAC's activities?

The paper is based on the content analysis of both writings and reports on the activity of the EAC, as well as the political and mass media discourse. The analysis will be based on social constructivism. ${ }^{3}$ The assumption is that actors (the EAC) may interact and affect the normative and the ideational structure, and shape the behavior of different entities (states, institutions, political elites, societies, etc.). However, the author does not attempt to take a comprehensive explanation of the relations between actors and structures, or to build assertions about the nature of cause and effect, but only to consider and understand this phenomenon.

\section{HISTORICAL BACKGROUND}

The East African Community is a regional intergovernmental organization of 6 partner states, these being Kenya, Tanzania, Uganda, Rwanda, Burundi and South Sudan. ${ }^{4}$ The work of the EAC is guided by its Treaty which was developed by Kenya, Tanzania and Uganda, signed on 30 November 1999 and which entered into force on 7 July 2000.5 As the document establishing the Community, it is recognized as one of the milestones in regional integration processes and another attempt at cooperation anew amongst the founding states.

The history of the institutional forms of cooperation between Kenya, Tanzania and Uganda dates back to the turn of the $21^{\text {st }}$ century. It is indicated that one of the first initiatives that may be considered as integration project was the launch of railway lines across Kenya, Uganda and Tanganyika under the management of the East African Railways Cooperation. ${ }^{6}$ The remaining events of importance include: the Customs Union between Kenya, Uganda and, later, Tanganyika established in 1917; the East African Currency Board, the Postal Union, the Court of Appeal for Eastern Africa, the East African Governors' Conference, the East African Income Tax Board and the Joint Economic Council established between 1905 and 1940; the East African Airways Corporation incorporated in 1946; and the East African Common Services Organization (EACSO) developed in 1961 (the organization replaced the East African High Commission). It is worth noting that cooperation in the EACSO was recognized as that which would lead to a political federation between the partner

See more: A. Wendt, Social Theory of International Politics, Cambridge 1999.

Rwanda and Burundi joined the EAC in 2007 and South Sudan in 2016.

5 “Overview of EAC", East African Community, at <https://www.eac.int/overview-of-eac>, 10 August 2018.

6 See more: D. Hyde, “The East African Railway Strike, 1959-60: Labour's Challenge of Inter-Territorialism”, Labor History, vol. 57, no. 1 (2016), at <https://doi.org/10.1080/0023656X.2016.1140625>. 
states if it had not been dominated by the economic position of Kenya. A similar scenario met the first East African Community, which operated between 1967 and 1977 and collapsed as a result of misunderstandings and final Kenya's dissolution of its membership.?

The genesis of modern integration processes in East Africa and the rise of the EAC refers to broader trends observed in sub-Saharan states. The analysis of these phenomena would contribute to a better understanding of present-day EAC activities therefore it is worth to consider and characterize the common points in the regionalism of East African states and the main tendencies in other sub-Saharan regions.

Therefore, it should be indicated that sub-regional organizations in Sub-Saharan Africa were established in several waves. The first one began after decolonization. At that time, the characteristic feature of most regional agreements was that they had their origin in the colonial period and were simply continued by the newly independent authorities. Moreover, those projects were cultivated without major corrections despite the enormous changes that have occurred after the withdrawal of European administration, ${ }^{8}$ which may suggest that they were recognized as still beneficial or were adapted due to the lack of alternative solutions. The second wave of integration processes occurred in the 1970s. On the one hand, this was determined by the idea of African unity; known as Pan-Africanism, and on the other, by successful cooperation in the European Community.9 As a result, in 1963 the Organization of African Unity (OAU) was established and despite the final failure of this organization, the OAU has been recognized as a milestone in developing regional cooperation in Sub-Saharan Africa. By spreading the values of freedom from colonialism and from apartheid the OAU grounded the idea of African unity and encouraged cooperation in individual regions; something that was reflected in the dynamic development of regional blocs. The last stage in modern integration processes took place in the 1990s. This was driven by several factors, such as: integration success in the European Union (EU); economic crises in many African states; and the end of most major conflicts in Sub-Saharan Africa. Prosperous cooperation among European states strengthened the belief that regional projects may be considered as guarantors of political and economic stabilization. ${ }^{10} \mathrm{At}$ the same time, the economic decline observed in most of the African states determined the authorities to implement new models of economic development. Therefore, many African governments decided to adopt the European integration model and simply follow the steps initiated in the EU. Finally, the post-conflict reality had been fostering the

“Timeline of East African Regional Integration", East African Community, at <https://www.eac. int/>, 10 September 2018.

8 D. Bach, "Regionalizm, integracja i transnarodowa regionalizacja w Afryce”, in K. Jędrzejczyk-Kuliniak et al. (eds.), Regionalizacja w stosunkach międzynarodowych..., p. 276.

9 G.M. Khadiagala, "Pan-Africanism and Regional Integration", in D.M. Anderson, N. Cheeseman, A. Scheibler (eds.), "Routledge Handbook of African Politics", London 2013, pp. 375-389.

10

R. Gibb, “Regional Integration...”, pp. 703-705. 
narrative as to the need to prevent a re-explosion of conflicts ${ }^{11}$ and as an answer for this requirement regional blocs were cited. ${ }^{12}$

Integration processes in the East Africa region and the launch of the EAC are parts of the trends described above. Firstly, one may observe that the genesis of cooperation between the founding states dates back to colonial times and has its continuation without major revisions after decolonization. Secondly, the regional mobilization initiated by the OAU has been correlated with an extensive EACSO activity. Thirdly, the EAC came into being in the 1990s, which are considered to be a period of intensive integration among EU structures and enthusiasm for regional projects in the world. Thus, it may be stated that major global integration ideas influenced regional cooperation in East Africa.

\section{COOPERATION IN EAST AFRICA REGION}

As it has been stated above, the East African states drew their integration ideas from the mainstream. At this point it is worth considering what the specific nature of cooperation between them is. Therefore, this part of the paper is devoted to analyzing the integration model adopted by the EAC and through this searching for an answer to this question. ${ }^{13}$

The EAC is based on four Pillars of Regional Integration; such as a Customs Union, Common Market, Monetary Union and Political Federation and the main aim of the organization is to construct a powerful and sustainable East African economic and political bloc ${ }^{14}$. Accordingly, at first sight, one may easily observe the inspiration of EU structures but further analyses leads one to develop a more complex picture of the EAC.

The Customs Union was established in $2005^{15}$ and the Common Market in 2010 16 , while Monetary Union and Political Federation remain open, in the sense that despite long talks and negotiations, they are still unfinished. The Protocol on Monetary Union was adopted in accordance with the EAC Treaty and signed in 2013. The document

11 A. Iwilade, "Women and Peace Talks in Africa", Journal of International Women's Studies, vol. 12, no. 1 (2011), p. 23.

12 It is also worth noting that in the 1980s. integration processes in sub-Saharan Africa slowed down. It is indicated that one of the few significant events was the elaboration of the Lagos Plan of Action, which served as a basis for the African Economic Community (AEC).

13 See more in: A. Cichecka, "Regionalizm i regionalizacja w Afryce Wschodniej", in A. Mania, M. Grabowski, J. Mormul (eds.), Problemy regionalne Azji, Afryki i Bliskiego Wschodu u progu XXI wieku, Warszawa 2018.

14 Treaty for the Establishment of the East African Community, East African Community (EAC), 1999.

15 Protocol on the Establishment of the East African Customs Union, East African Community (EAC), 2005.

16 Protocol on the Establishment of the East African Community Common Market, East African Community (EAC), 2010. 
lays the groundwork for a monetary union within 10 years and allows the EAC partner states to progressively converge their currencies into a single currency in the Community ${ }^{17}$ but as observers say, the achieving of this goal even now seems unrealistic. When it comes to Political Federation, the EAC declares it is the final goal of integration process in this region which would allow them to conduct a common foreign and security policy, and would also contribute to a more effective implementation of the previous stages of cooperation. Moreover, partner states underline that political cooperation would improve the region's stability and strengthen its position, especially in negotiations with world powers. For years, it has been also emphasized that the establishing of Political Federation must be treated as a long-term process and any speeded-up implementation is too risky and not needed. ${ }^{18}$ Therefore, one may observe again that this approach is similar to the attitude to EU member states.

However in 2004, in Nairobi, the EAC heads of state decided to launch the fasttrack mechanism which aims to accelerate and finalize the work on the Political Federation. ${ }^{19}$ This idea met with a large wave of criticism for a few reasons. Firstly, it has been assumed that the process of establishing political federation needs more time. Secondly, it has been noticed that the idea of political federation looks more like politicians' ambition than a well-planned answer for the social needs of the communities in this region. ${ }^{20}$ Moreover, this decision reveals further characteristics of the integration model adopted by the EAC, such as focusing on the perception of political elites and neglecting the social level of regional integration. The fast-track mechanism has been criticized for unrealistic goals that cannot be achieved in such a short period of time and without strengthening awareness of regional identity and informal connections among the Community.

It is also characteristic that the EAC does not speak with one voice and the relationship between partner states may be described as asymmetric. This situation is associated primarily with the dominant economic position of Kenya, which gives it an advantage, and leads to competition among partner states. In terms of economic and political stability Tanzania is just behind Kenya but it is worth noting that both states have played for the position of stronger for years. ${ }^{21}$ Rwanda is ahead of Kenya in terms of political stability and is similarly economically developed; however due to different historical conditions it does not attempt to be a rival. The weakest position is occupied by Burundi and the recently created South Sudan. Integration under the EAC gives the latter an opportunity for economic stabilization and independence from Sudan while

17 Treaty...

18 The EAC states that attainment of the Political Federation is a process and not an event.

19 "Timeline..."

20 K. Lyimo, "EAC Does Not Need Fast-Tracking Committees", The East African, 4 December 2006, at <http://www.theeastafrican.co.ke/oped/434748-252376-13nfvpe/index.html>, 10 September 2018.

21 "EAC Shaken as Neighbours Abandon Kenya Once Again", All East Africa, 5 February 2017, at $<$ https://www.alleastafrica.com/2017/02/05/eac-shaken-as-neighbours-abandon-kenya-onceagain/>, 10 September 2018. 
for the rest of the member states may mean profits related to the oil industry. The problem of the asymmetric relationship is strengthened by the overlapping memberships of multiple organizations. One may easily observe that EAC member states belong to other regional organizations - Kenya, Rwanda, Burundi and South Sudan to COMESA, ${ }^{22}$ Kenya and Uganda to IGAD, ${ }^{23}$ and Tanzania to SADC. ${ }^{24}$ As a result, they lobby for contradictory goals within different organizations; something that very often weakens the potential of the integration initiatives they participate in.

In the integration model adopted by the EAC the idea of African unity is also evident; as an example of which may serve again Political Federation. The striving for closer cooperation at this level is taking place despite significant limitations, as if in the name of higher values, such as: unity in general or just African unity in particular. The heads of states follow the vision of creating a strong regional player, ignoring the barriers described above and the internal disagreements within their own ranks.

Therefore, it may be stated that the process of integration in the East Africa region is similar to the EU only at first sight. However, a closer examination reveals differences and characteristic points in terms of cooperation in this region. This specific nature of regional activity is related to previous experience and historical dependencies of the relationship between partner states.

\section{RELEVANT SOLUTIONS OR DYSFUNCTIONAL PATTERNS}

The analyses presented above reveal that the EAC aspires to the role of a strong regional player whose actions will contribute not only to strengthening the region's position, but also contribute to the prosperity of the member states themselves. In this part of the paper an attempt has been made to trace the achievements and failures of the EAC and to try to find an answer as to whether the organization proposes relevant solutions for the major regional problems or rather maintains dysfunctional patterns in this area.

The list of the EAC's achievements opens with the harmonization of monetary and fiscal policies. The organization successfully made efforts to harmonize banking rules and regulations as well as finance ministries' pre- and post-budget consultations. ${ }^{25}$ This step not only facilitated work on the common budget in the Community but also contributed to the growth of trust between member states by eliminating some potential misunderstandings. Secondly, the EAC facilitated interstate road transport through reduced documentation for crews and vehicles at border crossings and harmonized immigration regulations. ${ }^{26}$ This has made transportation easier and encouraged traders from one member

22 "COMESA Member States", COMESA, at <http://www.comesa.int/comesa-members-states/>, 10 September 2018.

23 “The IGAD Region”, IGAD, at <https://igad.int/about-us/the-igad-region>, 10 September 2018.

24 “Member States", $S A D C$, at <http://www.sadc.int/member-states/>, 10 September 2018.

25 "Pillars of EAC Regional Integration", East African Community, at <https://www.eac.int/integration-pillars>, 12 September 2018.

26

Ibid. 
country to trade with traders from other member countries, contributing to the growth of economic ties and strengthening the economic position of the region. Thirdly, one may observe some accomplishments in education and the labour sectors, such as the introduction of free visas for students from member states to study at any university within this community. ${ }^{27}$ Finally, the EAC's partner states managed to promote tourism in this region and create the picture of East Africa as a single tourist destination. ${ }^{28}$

When it comes to the failures of the organization one may easily observe that the list of them is not much longer than the one of achievements. Then, at first sight, it seems that the EAC faces typical challenges but the vision to be a stable and politically united East Africa is still effective. Thus, the EAC faces criticism that the process of industrialization is too slow or even more, that there is a lack of substantial evidence with regard to industrialization. ${ }^{29}$ It has been pointed out that sustainable economic development is impossible and will remain unattainable until member states are industrialized. Then these allegations call into question the basic goals formulated by the EAC and reveal significant delays in solving major regional problems.

The next complaint relates to the Customs Union. One may observe that EAC failed to advance a custom union in accordance with the provisions of the Protocol. The document required Kenya to eliminate its tariffs on imports originating in Tanzania and Uganda respectively with immediate effect on the first day of the protocol implementation. ${ }^{30}$ However, charges in the gradually declining taxes remain for many products originating from Kenya that are exported to Tanzania and products originating from Kenya that are exported to Uganda. This situation is linked with the asymmetric relationship in the organization which implies additional problems. It may be stated that the revoking of agreements reflected different priorities and imbalanced benefits in force. This has led to the failure of ensuring that all countries benefit equally from the regional integration and simultaneously challenges the basic goals of the organization.

Another example which reveals serious difficulties within the EAC is the case of the Monetary Union. The organization has not met its 2012 target of agreeing on the formation of a monetary union. Following two years of negotiations, it was expected that a protocol would have started the process of monetary integration but it turned out that heads of states were unable to come to an agreement. Moreover, as has been stated above the problems with establishing Political Federation are also evident. They show the weakness of the organization in a particularly bright way, because they reveal dysfunctional patterns in many different areas, such as: the asymmetric relationship between member states, different priorities, imbalanced benefits, lack of dialogue between the political elites and the local community and ambitions inadequate to the possibilities. The impasse in the work on Political Federation also proves that the EAC

27 Ibid.

28 Ibid.

29 M. Busse, R. Shams, "Trade Effects of the East African Community: Do We Need a Transitional Fund?", HWWA Discussion Paper, no. 240, July 2003, at <http://dx.doi.org/10.2139/ssrn.439320>, 12 September 2018.

30 Protocol... 
failed in the creation of the 'People Centered Community'. It is stated that full political cooperation is impossible without social engagement, which should be based on the sense of a regional identity ${ }^{31}$ which simultaneously means that the EAC Partner States commit themselves towards putting 'the people' at the center of the regional integration process. However, this principle seems to exist only on paper and is not reflected in the actual practices of the organization. Therefore, it may be assumed that another principle from the Treaty for the Establishment of the EAC has failed.

When it comes to the current situation in the EAC, events that reflect the problems described above may be recognized as: Kenya's candidacy of the African Union Commission chairperson, ${ }^{32}$ civil strife in Burundi and South Sudan, and the re-routing of major regional infrastructure, railways and oil pipelines to the turning back on the Economic Partnership Agreement with the European Union. ${ }^{33}$

On the one hand, it may be assumed that the EAC has implemented many of the postulated goals and these may be treated as significant achievements. There is a reason it is recognized as one of the youngest sub-regional organization in Africa but at the same time the most advanced in the implementation of integration processes ${ }^{34}$. On the other hand, failures strike the bases of the organization, reveal serious difficulties in cooperation and reflect dysfunctional patterns from previous integration initiatives.

\section{CONCLUSION}

Firstly, it may be concluded that despite significant failures and internal problems in the EAC, the organization plays an important role in East Africa. It is the biggest regional bloc, well known among Sub-Saharan countries as well as worldwide, with a long history of cooperation. The position of member states is stronger due to them belonging to the EAC as evidenced by the efforts undertaken by South Sudan to join the organization. The EAC contributes to the economic development of the region and it seems that economic cooperation is the trump card within the organization.

Secondly, one may observe some characteristic points in East African cooperation, such as: its asymmetric relationship, different priorities, and imbalanced benefits, overlapping memberships within multiple organizations, lack of dialogue between the political elites and the local community and ambitions inadequate to the possibilities. It may be assumed that this specific nature of the group determines its activity and

31 P. Protas, T. Romward, "Reflections on 'People Centered Principle' in the East African Community: The Current Legal Controversy”, University of Dar es Salaam Journals, vol. 42, no. 2 (2015), pp. 4-6.

32 H. Mohamed, "Chad's Moussa Faki Mahamat Named AU Commission Chair", News/African Union, 30 January 2017, at <https://www.aljazeera.com/news/2017/01/chad-moussa-faki-mahamat-named-african-union-leader-170130145612950.html>, 12 September 2018.

33 M. Alot, "EAC at a Major Crossroads after Addis Debacle", The Citizen, 8 February 2018, at <http:// www.thecitizen.co.tz/magazine/politicalreforms/EAC-at-a-major-crossroads-after-Addis-debacle/1843776-3804856-65b4aez/index.html>, 12 September 2018.

34 W. Lizak, Afrykańskie instytucje bezpieczeństwa, Warszawa 2012, p. 425. 
as a result leads to the achievements and failures which have been described above. Moreover, cooperation under the EAC is accompanied by a meta-narrative about African unity and diverse, often inconsistent narratives about integration at the regional level. It is evident that those concerning the Political Confederation and community are shaped mostly by political elites. Therefore, the group does not create new patterns of social or political behavior but only favors economic strategies.

Finally, it may be said that the model adopted by the EAC maintains dysfunctional patterns in the organization and among the partner states to some extent. The dominant position of political elites reflects paternalistic patterns which are characteristic for the member states and which are considered as negative for cohesive development. Moreover, it is worth noting that the EAC does not have effective mechanisms to regulate the competition and disloyalty of member states. It is also reasonable to consider whether the weakness of the group is not determined by adopting a model of integration similar to the EU structures as any its adaptation to different economic, political and social conditions may cause limitations.

\section{BIBLIOGRAPHY}

Alot M., "EAC at a Major Crossroads after Addis Debacle", The Citizen, 8 February 2018, at <http://www.thecitizen.co.tz/magazine/politicalreforms/EAC-at-a-major-crossroads-after-Addis-debacle/1843776-3804856-65b4aez/index.html >.

Bach D., "Regionalizm, integracja i transnarodowa regionalizacja w Afryce", in K. Jędrzejczyk-Kuliniak et al. (eds.), Regionalizacja w stosunkach międzynarodowych. Aspekty polityczno-gospodarcze, Torun 2008.

Busse Mt., Shams R., "Trade Effects of the East African Community: Do We Need a Transitional Fund?", HWWA Discussion Paper 240, July 2003, at <https://ageconsearch.umn.edu/bitstream/26290/1/dp030240.pdf>, at <http://dx.doi. org/10.2139/ssrn.439320>.

Cichecka A., "Regionalizm i regionalizacja w Afryce Wschodniej", in A. Mania, M. Grabowski, J. Mormul (eds.), Problemy regionalne Azji, Afryki i Bliskiego Wschodu u progu XXI wieku, Warszawa 2018.

"COMESA Member States". COMESA, at <http://www.comesa.int/ comesa-members-states/>.

"EAC Shaken as Neighbours Abandon Kenya Once Again", All East Africa, 5 February 2017, at <https://www.alleastafrica.com/2017/02/05/eac-shakenas-neighbours-abandon-kenya-once-again/> .

Gibb R., "Regional Integration and Africa's Development Trajectory: Meta-Theories, Expectations and Reality", Third World Quarterly, vol. 30, no. 4 (2009), at <https://doi.org/10.1080/01436590902867136>.

Hyde D., "The East African Railway Strike, 1959-60: Labour's Challenge of Inter-territorialism", Labor History, vol. 57, no. 1 (2016), at <https://doi.org/10.1080/002 3656X.2016.1140625>. 
Iwilade A., "Women and Peace Talks in Africa", Journal of International Women's Studies, vol. 12, no. 1 (2011), pp. 22-37.

Khadiagala G.M., "Pan-Africanism and Regional Integration", in D.M. Anderson, N. Cheeseman (eds.), An Introduction to African Politics, Palgrave 2013.

Lizak W., Afrykańskie instytucje bezpieczeństwa, Warszawa 2012.

Lyimo K., "EAC does not need fast-tracking committees", The East African, 4 December 2006, at <http://www.theeastafrican.co.ke/oped/434748-252376-13nfvpe/ index.html $>$.

"Member States", SADC, <at http://www.sadc.int/member-states/>.

Mohamed H., "Chad's Moussa Faki Mahamat named AU Commission chair", News/ African Union, 30 January 2017, at <https://www.aljazeera.com/news/2017/01/ chad-moussa-faki-mahamat-named-african-union-leader-170130145612950. html>.

"Overview of EAC", East African Community, at <https://www.eac.int/ overview-of-eac $>$.

"Pillars of EAC Regional Integration", East African Community, at <https://www.eac. int/integration-pillars>.

Protas P., Romward T., "Reflections on 'People Centered Principle' in the East African Community. The Current Legal Controversy", University of Dar es Salaam Journals, vol 42, no 2 (2015).q

Protocol on the Establishment of the East African Customs Union, East African Community (EAC), 2005.

Protocol on the Establishment of the East African Community Common Market, East African Community (EAC), 2010.

Stadtmüller E., "Regionalizm i regionalizacja jako przedmiot badań naukowych w stosunkach międzynarodowych”, in Katarzyna Jędrzejczyk-Kuliniak et al. (eds.), Regionalizacja w stosunkach międzynarodowych. Aspekty polityczno-gospodarcze, Toruń 2008.

"The IGAD Region", IGAD, at <https://igad.int/about-us/the-igad-region>.

Treaty for the Establishment of the East African Community, East African Community (EAC), 1999.

“Timeline of East African Regional Integration”, East African Community, at <https:// www.eac.int/>.

Wendt A., Social Theory of International Politics, Cambridge 1999.

Anna CICHECKA, M.A. - PhD Student in political sciences at the University of Wroclaw. In her research she focuses on the socio-political situation in Sub-Saharan Africa with particular emphasis on the situation of women and the role of NGO sector in democratization processes in developing countries. She is a grant holder and head of research projects financed by the National Science Center and the University of Wroclaw, as well as the author of numerous publications. 